\title{
Genetic variability in physic nuts cultivated in Northeastern Brazil
}

\author{
Variabilidade genética de pinhão manso cultivado no Nordeste do Brasil
}

\author{
Vanice Dias Oliveira ${ }^{\mathrm{I}}$ Allivia Rouse Carregosa Rabbani ${ }^{\mathrm{II}}$ Ana Veruska Cruz da Silva ${ }^{\mathrm{II}{ }^{*}}$ \\ Ana da Silva Lédo ${ }^{\text {III }}$
}

\begin{abstract}
This research had as objective to characterize genetically individuals of physic nut cultivated in experimental areas in Sergipe, Brazil by means of RAPD molecular markers. Leaves of 40 individuals were collected and DNA was isolated using CTAB 2\% method. Were used 30 primers RAPD for DNA amplification, and this data was used to estimate the genetic similarity among the pairs of individuals, using Jaccard coefficient, and group them out for the UPGMA method. Also, the genetic structure and diversity of the populations were assessed using AMOVA. Of the 100 fragments generated, 29 of were polymorphic. A similarity average of 0.54 among the individuals was found and the amplitude similarities varied from 0.18 to 1.00. One of them (U5) was unit clusters and formed by the most divergent individuals. AMOVA indicated that there is more variation within (63\%) the population. In conclusion, it was possible verify genetic variability in physic nut using RAPD markers at these experimental areas.
\end{abstract}

Key words: Jatropha curcas L., RAPD, genetic diversity.

\section{RESUMO}

O trabalho teve como objetivo caracterizar genótipos de pinhão manso cultivados em áreas experimentais do Estado de Sergipe no Brasil, por meio de marcadores moleculares RAPD. Foi utilizada a metodologia CTBA $2 \%$ para extração do DNA de 40 genótipos e para a amplificação do DNA foram utilizados 30 primers RAPD. Os dados foram utilizados para estimar a similaridade genética entre pares de genótipos, usando o coeficiente de Jaccard e o método UPGMA para agrupamento e avaliação da estrutura genética e diversidade de populações usando AMOVA. Fragmentos (100) foram gerados, sendo 29 polimórficos. A similaridade encontrada foi de 0,54 entre genótipos, sendo que a amplitude variou de 0,18 a 1,00. $O$ genótipo U5 foi o mais divergente, agrupado isoladamente dos demais. A AMOVA indicou que a maior variação é encontrada dentro da população (63\%). É possivel verificar a variabilidade genética em pinhão manso usando marcadores RAPD nas áreas experimentais estudadas.

Palavras-chave: Jatropha curcas $L ., R A P D$, diversidade genética.

\section{INTRODUCTION}

Jatropha curcas L., known as jatropha or physic nut, is a Euphorbia native to tropical America, which has been used since ancient times in medical applications, lighting homes and villages, soap production and as a hedge (HELLER, 1996). Currently, for bringing features like easy propagation, good adaptation to semi-arid regions, tolerance to drought and high oil content, which has made the plant attractive to programs to combat erosion, desertification (WIESENHÜTTER, 2003) and especially for biofuel production, causing large investments and rapid expansion of cultivated areas in over 50 countries (BASHA \& SUJATHA, 2009).

In Brazil, the planting of physic nut has been widely encouraged and in many parts of the country, as can be found in several areas of cultivation, estimated at more than 30.000 hectares (MENDONÇA \& LAVIOLA, 2009). However, it is a culture that lacks scientific evidence on its real productive potential and agronomic properties, and

IPrograma de Pós-graduação em Agroecossitemas, Universidade Federal de Sergipe (UFS), São Cristovão, SE, Brasil.

"UFS, São Cristovão, SE, Brasil.

IIIEmbrapa Tabuleiros Costeiros, Av. Beira mar, 3250, Jardins, 49025-040, Aracaju, SE, Brasil. E-mail: ana.veruska@embrapa.br. *Autor para correspondência. 
there are no improved cultivars to be recommended with confidence. This can lead to unsustainable practices with economic, social and environmental risks. Thus, to reduce them and improve plant performance in different agro-climatic conditions is essential to invest in domestication, characterization, selection and breeding.

The molecular markers appear as an available tool for the detection of variability at the DNA level. Among them, the RAPD (Random Amplified Polymorphic DNA) technique is the most accessible, to have lower cost, number of steps and greater speed in getting the results.

In physic nut, the RAPD has also been employed in many papers, such as access to distinguish toxic and nontoxic and measure the degree of genetic similarity in different populations (IKBAL et al., 2010).

RAM et al. (2008) and PAMIDIMARRI et al. (2009) have used the technique in order to establish phylogenetic relationships, found specific brands able to discriminate species of Jatropha and identify interspecific hybrids between them. Information about the genetic diversity of existing materials physic nut in Brazil is limited, especially in areas where there are experimental crops.

Thus, in order to contribute to the characterization of population this study aimed to assess the genetic diversity of physic nut individuals, cultivated in experimental areas of Sergipe, Brazil, using RAPD molecular markers.

\section{MATERIAL AND METHODS}

Plant material - The selected 40 individuals of physic nut were planted experimentally in two areas in Sergipe, Brazil: Umbaúba (U1 to U20) implemented in the experimental field belonging

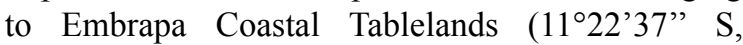
$\left.37^{\circ} 40^{\prime} 26^{\prime \prime} \mathrm{W}\right)$, and Carira (U21 to U40) (10²1'42' $\left.\mathrm{S}, 37^{\circ} 42^{\prime} 01^{\prime \prime} \mathrm{W}\right)$, particular propriety.

DNA extraction and RAPD reaction Young leaves were used, and the methodology was based on DOYLE \& DOYLE (1990). Each RAPD reaction was performed in $25 \mu \mathrm{L}$ volume containing 50ng genomic DNA, 5.0 $\mu \mathrm{L}$ 10X PCR buffer(Promega, USA), $2.5 \mathrm{mM}$ dNTP, 5U Taq DNA polymerase (GIBCO), 30ng $\mu \mathrm{L}^{-1}$ primer, $14.8 \mu \mathrm{L}$ ultrapure water PCR amplifications - Were performed using a PTC100 thermocycler (Programmable Thermal Controller - MJ Research, Inc.) and subjected to a cycle of $96^{\circ} \mathrm{C}$ for 5 minutes for initial denaturation, followed by 35 cycles of denaturation at $96^{\circ} \mathrm{C}$ for 45 seconds, $36^{\circ} \mathrm{C}$ for 45 seconds for primer annealing, $72^{\circ} \mathrm{C}$ for 45 seconds for extension, and finally one cycle of $72^{\circ} \mathrm{C}$ for 5 minutes for final extension (SILVA \& MARTINS, 2006). We tested 30 primers (Table 1). It was used for each primer, a reaction control (negative control - NC), which was added ultrapure water as a substitute of DNA.

Electrophoresis - $10 \mu \mathrm{L}$ of PCR products were mixed to $1.5 \mu \mathrm{L}$ of blue juice $(0.01 \%$ bromophenol blue, $40 \%$ glycerol). We used $1.5 \%$ agarose gel (1X TEB - 89mM TRIS, $89 \mathrm{mM}$ boric acid, 2.5mM EDTA, $\mathrm{pH} 8.3$ ) in a horizontal electrophoresis system Sunrise (Gibco BRL), carried out at a constant voltage of $100 \mathrm{~V}$ for 90 minutes. Gel was stained with ethidium bromide solution $\left(5 \mathrm{mg} \mathrm{mL}^{-1}\right)$ for 15 minutes, and the amplification products visualized under ultraviolet light using a Gel Doc L-Pix image system (Loccus Biotecnologia, Brazil).

Statistical analysis - Bootstrap procedure was applied to calculate variance of the genetic distance obtained from markers, and was obtained from 5.000 bootstrap random draws using the DBOOT software (COELHO, 2001). Polymorphic information content (PIC) was calculated according to GHISLAIN et al. (1999). The marker index (MI) was determined as described in ZHAO et al. (2007). To measure the genetic diversity, we used Genalex v.6.3 (www.anu.edu.au/BoZo/GenAlEx/) and calculated the Shannon Index (I) (BROWN \& WEIR 1983), the genetic diversity (H) (MAGUIRE et al., 2002), the Analysis of Molecular Variance (AMOVA), PhiPT value for genetic variability for dominant marker, and Principal coordinates analysis (PCoA). The data matrix of the RAPD scores was generated and similarity coefficients were calculated using Jaccard's arithmetic complement index (JC). The dendrogram was constructed using the Unweighted Pair Group Method with Arithmetic Mean (UPGMA) cluster algorithm. In order to determine the robustness of the dendrogram, the data was bootstrapped with 5.000 replications using FreeTree software (http:// web.natur.cuni.cz/flegr/programs/freetree.htm). For visualization of the cluster we used the TreeView package (http://web.natur.cuni.cz/flegr/programs/ freetree/TreeView.exe).

\section{RESULTS AND DISCUSSION}

A total of 100 fragments (TF) were generated by 30 primers, $29 \%$ polymorphic. The highest number of polymorphic fragments (PF) was obtained from A19 primer (four) (Table 1). Fourteen primers (A02, A04, A10, A15, A16, A20, B11, B18, IDT3, IDT5, S01, W08, W03, X01) had

Ciência Rural, v.43, n.6, jun, 2013. 
Oliveira et al.

Table 1 -Molecular characterization of 40 physic nut cultivated in Sergipe, Brazil.

\begin{tabular}{|c|c|c|c|c|c|}
\hline Primers & Sequence $5^{\prime}-3^{\prime}$ & $\mathrm{TF}$ & $\mathrm{PF}$ & PIC & MI \\
\hline A02 & TGC CGA GCT G & 2 & 0 & 0.00 & 0.00 \\
\hline A04 & AAT CGG GCT G & 3 & 0 & 0.00 & 0.00 \\
\hline $\mathrm{A} 10$ & GTG ATC GCA G & 2 & 0 & 0.00 & 0.00 \\
\hline A11 & CAA TCG CCG T & 5 & 3 & 0.34 & 1.01 \\
\hline $\mathrm{A} 12$ & TCG GCG ATA G & 4 & 1 & 0.23 & 0.23 \\
\hline A13 & CAG CAC CCA C & 3 & 2 & 0.33 & 0.66 \\
\hline A15 & TTC CGA ACC C & 6 & 0 & 0.00 & 0.00 \\
\hline A16 & AGC CAG CGA A & 3 & 0 & 0.00 & 0.00 \\
\hline A17 & GAC CGC TTG T & 4 & 2 & 0.28 & 0.56 \\
\hline A18 & AGG TGA CCG T & 2 & 1 & 0.09 & 0.09 \\
\hline A19 & CAA ACG TCG G & 5 & 4 & 0.43 & 1.71 \\
\hline A 20 & GTT GCG ATC C & 2 & 0 & 0.00 & 0.00 \\
\hline B11 & GTA GAC CCG T & 2 & 0 & 0.00 & 0.00 \\
\hline B18 & CCA CAG CAG T & 2 & 0 & 0.00 & 0.00 \\
\hline K20 & CAG AAG CGG A & 4 & 3 & 0.46 & 1.38 \\
\hline S01 & GAC TGC CTC T & 2 & 0 & 0.00 & 0.00 \\
\hline $\mathrm{S} 18$ & CAC AGC GAC A & 4 & 1 & 0.14 & 0.14 \\
\hline W02 & CAA AGC GCT C & 3 & 1 & 0.25 & 0.25 \\
\hline W03 & CAG GCC CTT C & 2 & 0 & 0.00 & 0.00 \\
\hline W04 & GTT TCG CTC C & 3 & 1 & 0.47 & 0.47 \\
\hline W08 & TTC GAG CCA G & 4 & 0 & 0.00 & 0.00 \\
\hline W13 & GTG AGG CGT C & 4 & 1 & 0.40 & 0.40 \\
\hline W19 & CCC AAG GTC C & 5 & 3 & 0.37 & 1.10 \\
\hline X01 & GGA GGA GAG G & 6 & 0 & 0.00 & 0.00 \\
\hline IDT01 & GTG TCG CGA G & 3 & 1 & 0.14 & 0.14 \\
\hline IDT03 & CTA CTG GCG T & 2 & 0 & 0.00 & 0.00 \\
\hline IDT05 & CTG GCG AAC T & 1 & 0 & 0.00 & 0.00 \\
\hline IDT06 & CTG GGC ACG A & 3 & 1 & 0.23 & 0.23 \\
\hline IDT09 & ACC CCG CCA A & 4 & 2 & 0.13 & 0.25 \\
\hline IDT18 & GTC CGG AGT G & 5 & 2 & 0.30 & 0.60 \\
\hline Total /Average & & 3 & 1 & 0.15 & 0.31 \\
\hline
\end{tabular}

no polymorphic fragments. The PIC values ranged from 0.09 (A18) to 0.47 (W04) and MI variation was between 0.09 (A18) and 1.71 (A19).

The low polymorphism level found in our study $(29 \%)$ corroborated with those obtained by ROSADO et al. (2009). Even with low polymorphism, BASHA et al. (2009) distinguished non-toxic Mexican accessions of physic nut, and a greater degree of variability among accessions of the Central America (Mexico and El Salvador countries) and lowest among accessions Asia and Africa countries.

By DBOOT software, results from 23 polymorphic fragments there is a stabilization of the variance. There is a directly proportional relationship between the number of fragments analyzed and the variance, with value less than 0.01 , suggesting that the results obtained by the fragments used in this study
(29) can be used for analysis of diversity, according to SILVA et al. (2012).

We computed Jaccard coefficient (JC) based on the binary data and individuals were clustered by the UPGMA (Figure 1). The average genetic similarity among individuals was 0.54 ( \pm 0.09 ), ranging 0.18 (U5 and C36) to 1.00 (C39 and C40). UPGMA method according JC, six groups have a high similarity above $0.60 \mathrm{JC}$, and maximum of 1.00 JC sustained by bootstraps analysis. G1 and G5 had one individual each (U5 and U3, respective), G3 and G4 eight, G6 six, and G2 consisting of 16 individuals from Carira city (U25-40). This variability expressed should be used in breeding programs and studies, multiplication of top individuals.

The presence of individuals with high level of similarity in one area may be possible, since 


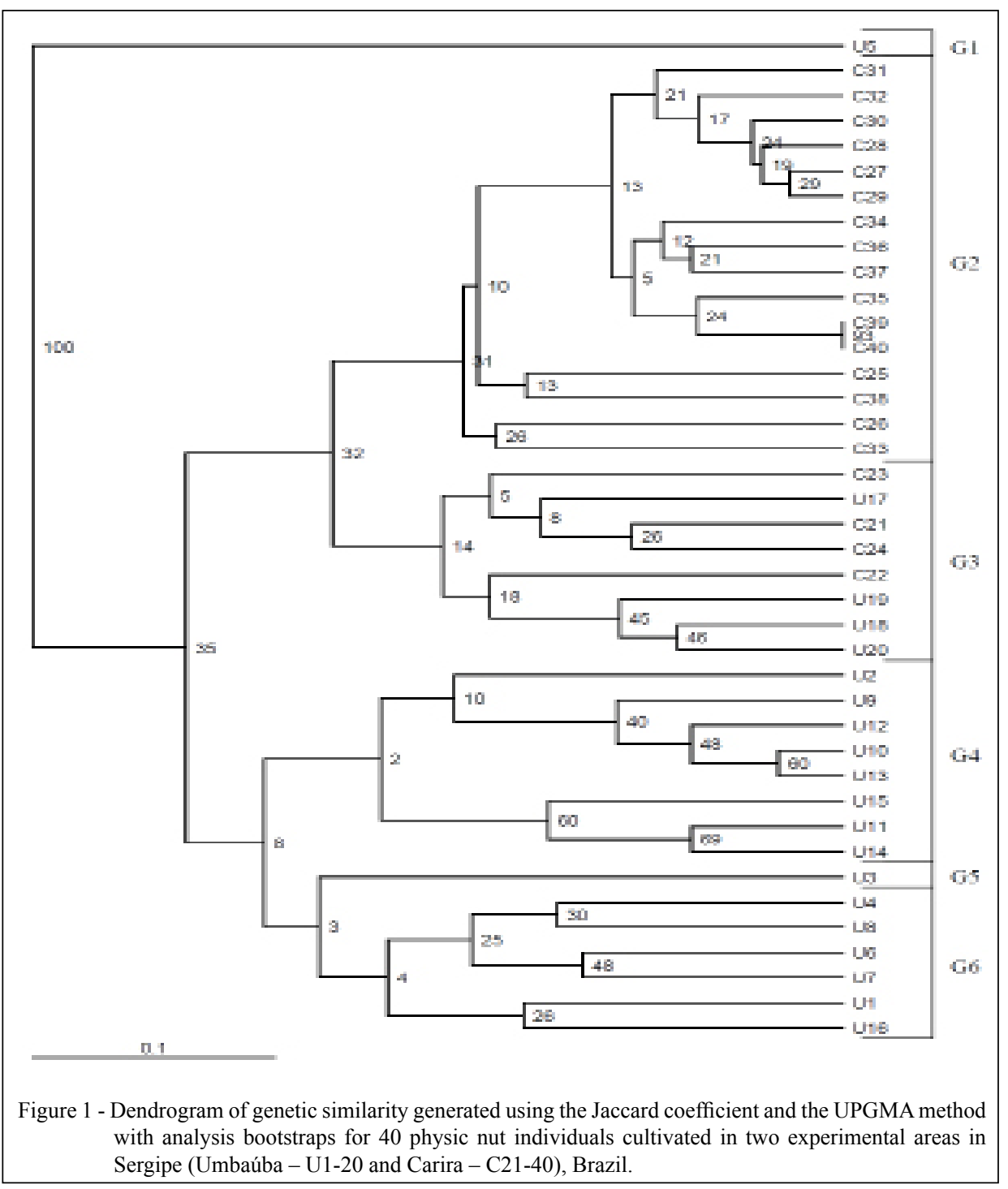

with the use of co-dominant markers in physic nut and inbreeding have been observed in homozygous locus (SUN et al., 2008; BASH et al., 2009), assigned to the mode of propagation, geitonogamy (pollination between different flowers of the same plant), as well as apomixis (PAIVA NETO et al., 2010). To raise this variability, some researchers suggest hybridization with other species of the genus Jatropha. Authors such as BASHA \& SUJATHA (2009) and PARTHIBAN et al. (2009) developed successfully, interspecific hybrids between $\boldsymbol{J}$. curcas and $\boldsymbol{J}$. impeccable, which showed gains in seed size, oil content and increased resistance to drought, pests and diseases.

Considering the method of principal coordinates analysis (ACoP), the individuals were grouped in eight groups (Figure 2). The subclusters of the groups detected in the dendrogram appear unaided. The individuals C26 (GVI) and U5 (GII) are isolated.

It was observed in the formation of a single group, with G5, and another larger group (GII), with $80 \%$ of individuals Carira city, also showing greater similarity in this region (Figure 1). Crossing information between clusters, it was evident that the U3 and U5 individuals were more divergent. In the case where the clusters reflected that there was no clear similarity between groups IKBAL et al. (2010) explain the selection can be based on either on the phenotypic traits or on the molecular markers separately. However, selection based on molecular markers is likely to be more effective as it is more closely linked to the genetic constitution of a genotype. In our study, the results can be used in

Ciência Rural, v.43, n.6, jun, 2013. 


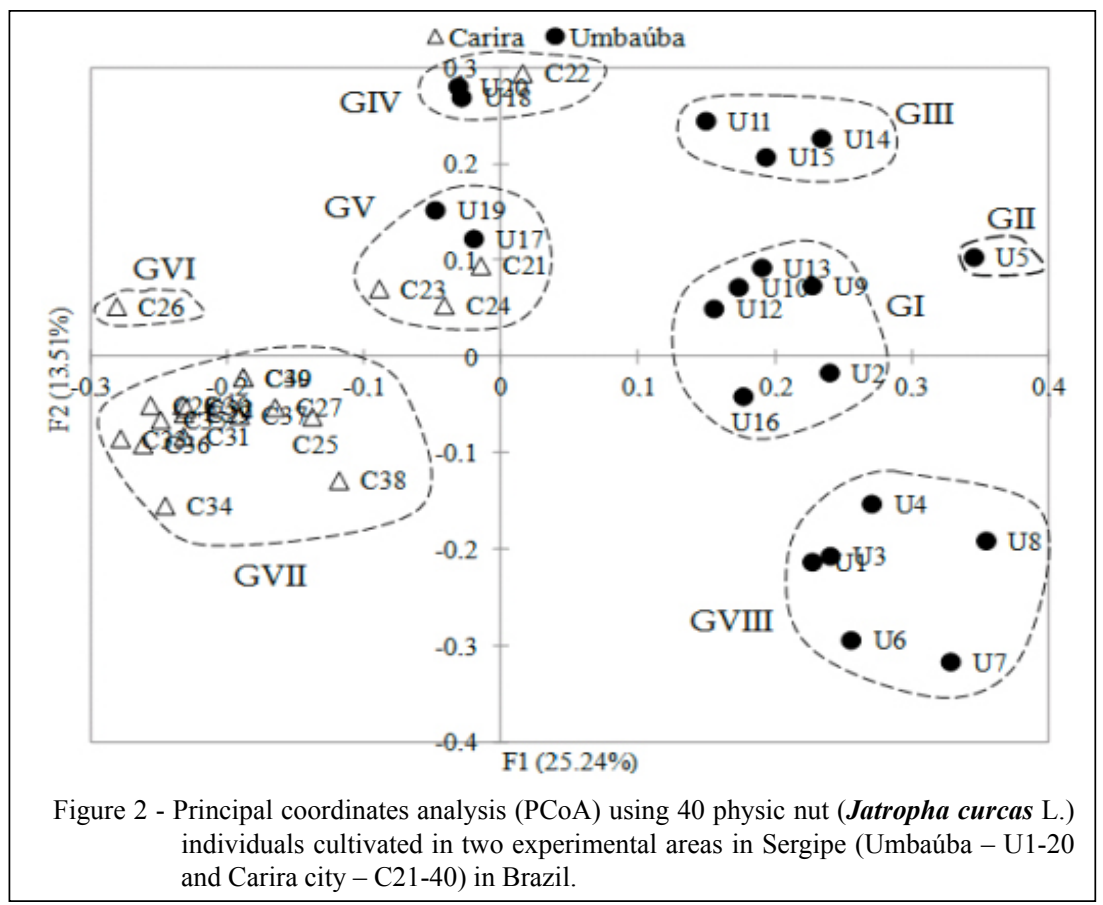

breeding programs, in order to increase the variability between cycles of selection. Can be use especially for individuals who presented greater divergence for the UPGMA and ACoP.

AMOVA performed by original location showed a genetic differentiation of $37 \%(\mathrm{P}<0.001)$ with PhiPT of 0.37 , and by PCoA groups only accounted for $57 \%(\mathrm{P}<0.001)$ and PhiPT of 0.56 (Table 2). The high similarity of the two groups found in the experimental fields of Sergipe State should not promote an exclusion of these new studies, it is suggested to more homogeneous groups with each other is made a morphoagronomic characterization of qualitative and quantitative nature to found agronomic characteristics interesting, would also be motivating to include new individuals coming from other areas of planting or even be tempted hybridization with other species or genotypes between groups.

The populations demonstrated different means of genetic diversity. The Shannon index had the high value for populations by origins (0.47), followed to dendrogram groups $(0.31)$, and PCoA groups (0.22). The genetic diversity had a similar behavior to Shannon Index (Table 3). The nonzero values for the genetic structure, particularly for $\mathrm{H}$, indicate that there is an excess of heterozygous or homozygous (BARREIRA et al., 2006). Physic nut species had a $95 \%$ cross-pollination (CARVALHO et

Table 2 - Analysis of molecular variance (AMOVA) of 40 physic nut individuals cultivated in two experimental areas in Sergipe, Brazil, by original location, dendrogram and ACoP groups.

\begin{tabular}{|c|c|c|c|c|}
\hline Original location & $\mathrm{df}^{1}$ & Est. Variance & Variation (\%) & $\mathrm{PhiPT}^{2}$ \\
\hline Among & 1 & 2.51 & $37 \%$ & $0.37 * * *$ \\
\hline Within & 38 & 4.27 & $63 \%$ & \\
\hline Dendrogram group & $\mathrm{df}^{1}$ & Est. Variance & Variation $(\%)$ & PhiPT \\
\hline Among & 3 & 3.29 & $52 \%$ & $0.52 * * *$ \\
\hline Within & 34 & 3.00 & $48 \%$ & \\
\hline PCoAs group & $\mathrm{df}^{1}$ & Est. Variance & Variation (\%) & PhiPT \\
\hline Among & 5 & 3.53 & $57 \%$ & $0.56 * * *$ \\
\hline Within & 32 & 2.67 & $43 \%$ & \\
\hline
\end{tabular}

1- Degrees of freedom, $* * * \mathrm{P}<0.001 ; 2$ - Analogue of FST fixation index.

Ciência Rural, v.43, n.6, jun, 2013. 
Table 3 - Values of Shannon's Information Index (I) and genetic diversity $(\mathrm{H})$ to $40 \mathrm{p}$ hysic nut (Jatropha curcas L.) individuals cultivated in two experimental areas in Sergipe (Umbaúba and Carira city) in Brazil by original location, dendrogram and ACoP groups.

\begin{tabular}{lll}
\hline Original location & $\mathrm{I}$ & $\mathrm{H}$ \\
\hline Umbaúba city & 0.49 & 0.33 \\
Carira city & 0.46 & 0.31 \\
Mean & 0.47 & 0.32 \\
Dendrogram groups & $\mathrm{I}$ & $\mathrm{H}$ \\
G2 & 0.34 & 0.23 \\
G3 & 0.35 & 0.25 \\
G4 & 0.32 & 0.22 \\
G6 & 0.23 & 0.15 \\
Mean & 0.31 & 0.21 \\
PCoA groups & $\mathrm{I}$ & $\mathrm{H}$ \\
GI & 0.23 & 0.16 \\
GII & 0.10 & 0.07 \\
GIV & 0.16 & 0.11 \\
GV & 0.29 & 0.20 \\
GVII & 0.33 & 0.22 \\
GVIII & 0.21 & 0.14 \\
Mean & 0.22 & 0.15 \\
\hline
\end{tabular}

al., 2009) is expected to have a great diversity and distinction between genotypes propagated by seminal most likely to incorporate new alleles.

\section{CONCLUSION}

It was possible to detect the genetic variation in physic nut from Brazil with RAPD analysis. The study verified that the areas cultivated show low genetic diversity among the individuals groups, confirmed by genetic structure and genetic similarity and variability.

\section{REFERENCES}

BARREIRA, S. et al. Diversidade genética e sistema de reprodução em população nativa de Eremanthus erythropappus (DC.) MacLeish sob exploração. Scientia Forestalis, n.71, p.119130, 2006. Available from: <http://www.ipef.br/publicacoes/ scientia/nr71.asp>. Accessed: Jan. 12, 2010.

BASHA, S.D. et al. A comparative study of biochemical traits and molecular markers for assessment of genetic relationships between Jatropha curcas L. germplasm from different countries. Plant Science, v.176, p.812-823, 2009. Available from: <http:// www.sciencedirect.com/science/article/pii/S0168945209000934>. Accessed: Jan. 12, 2010. doi: 10.1016/j.plantsci.2009.03.008.

BASHA, S.D.; SUJATHA, M. Genetic analysis of Jatropha species and interspecifc hybrids between Jatropha curcas using nuclear and organelle specific markers. Euphytica, v.168, n.2, p.197-214, 2009. Available from: <http://www.springerlink.com/ content/r54761662n631870/>. Accessed: Feb. 02, 2010. doi: 10.1007/s10681-009-9900-0.

BROWN, A.H.D.; WEIR, B.S. Measuring genetic variability in plant populations. In: TANKSLEY S.D.; ORTON T.J. Isozymes in plant genetics and breeding. Amsterdam: Elsevier Science, 1983. Part A, p.219-239. Available from: <http://www.ableweb. org/volumes/vol-19/2-bader.pdf>. Accessed: Dec. 10, 2009.

CARVALHO, B.C.L. et al. Informações técnicas para o cultivo do pinhão-manso no Estado da Bahia. Salvador: EBDA, 2009. 79p.

COELHO, A.S.G. DBOOT - Avaliação dos erros associados a estimativas de distâncias/similaridades genéticas através do procedimento de bootstrap com número variável de marcadores, versão 1.1. Goiânia: Departamento de Biologia Geral, Instituto de Ciências Biológicas, Universidade Federal de Goiás, 2001. Cd-room.

DOYLE, J.J.; DOYLE, J.L. Isolation of plant DNA from fresh tissue. Focus, v.12, p.13-15, 1990.

GHISLAIN, M. et al. Marker assisted sampling of the cultivated Andean potato Solanum phureja collections using RAPD markers. Genetic Resourse and Crop Evolution, v.46, p.547555, 1999. Available from: <http://www.springerlink.com/ content $/ \times 4 \times 113 g 73662 v 344 />$. Accessed: Feb. 25, 2010. doi: 10.1023/A:1008724007888.

HELLER J. Physic nut-Jatropha curcas L. promoting the conservation and use of underutilized and neglected crops. Rome: International Plant Genetic Resources Institute, 1996. 66p. Available from: <http://books.google.com.br/books?id=NgrKy17 M6bgC\&printsec $=$ copyright\&hl $=$ pt $-\mathrm{BR} \# \mathrm{v}=$ onepage\& $\mathrm{q} \& \mathrm{f}=$ false $>$. Accessed: Dec. 11, 2009.

IKBAL, K. et al. Evaluation of genetic diversity in Jatropha curcas L. using RAPD markers. Indian Journal of Biotechnology, v.9, p.50-57, 2010. Available from: <http://nopr.niscair.res.in/ bitstream/123456789/7124/1/IJBT\%209\%281\%29\%2050-57. pdf>. Accessed: Jun. 07, 2010.

MAGUIRE, T.L. et al. Comparative analysis of genetic diversity in the mangrove species Avicennia marina (Forsk.) Vierh. (Avicenniaceae) detected by AFLPs and SSRs. Theoretical and Applied Genetics, v.104, p.388-398, 2002. Available from: $<$ http://www.springerlink.com/content/m2k957jhrhrtaw01/>. Accessed: Jan. 12, 2010. doi: 10.1007/s001220100724.

MENDONÇA, S.; LAVIOLA, B.G. Uso potencial e toxidez da torta de pinhão-manso. Brasília, DF: Embrapa Agroenergia, 2009. 8p. (Comunicado Técnico, 1). Available from: $<$ http://www.alice. cnptia.embrapa.br/bitstream/doc/578316/1/MendoncaLaviola123. pdf>. Accessed: Jun. 08, 2010.

PAIVA NETO, V.B. de et al. Aspectos da biologia reprodutiva de Jatropha curcas L. Ciência e Agrotecnologia, v.34, n.3, p.558-563, 2010. Available from <http://www.scielo.br/scielo. php?script $=$ sci_arttext\&pid $=$ S1413-70542010000300005\&lng $=$ en $\&$ nrm $=$ iso $>$. Access: Jun. 28, 2011. doi: 10.1590/S141370542010000300005 .

PAMIDIMARRI, D.V.N.S. et al. Comparative study of interspecific genetic divergence and phylogenic analysis of genus Jatropha by RAPD and AFLP. Molecular Biology Reports, v.36, p.901-907,

Ciência Rural, v.43, n.6, jun, 2013. 
2009b. Available from: <http://www.springerlink.com/content/ m642ml6440657117/fulltext.pdf $>$. Accessed: Jan. 10, 2011. doi: 10.1007/s11033-008-9261-0.

PARTHIBAN, K.T. et al. Hybrid progenies in Jatropha - a new development. Current Science, v.96, n.6, p.815-823, 2009. Available from: <http://apps.webofknowledge.com/full record. do? product $=$ WOS\&search $\_$mode $=$GeneralSearch \&qid $=4 \& \overline{S I D}=3 \mathrm{~F}$ m7O8jgBp9McHc91o6\&page=1\&doc=1>. Accessed: Jun. 28, 2011.

RAM, S.G. et al. Genetic diversity among Jatropha species as revealed by RAPD markers. Genetic Resources and Crop Evolution, v.55, p.803-809, 2008. Available from: <http://apps. webofknowledge.com/full_record.do?product=WOS\&search_mo $\mathrm{de}=$ GeneralSearch \&qid $=8 \& \mathrm{SID}=3 \mathrm{Fm} 7 \mathrm{O} 8 \mathrm{jgBp} 9 \mathrm{McHc} 91 \mathrm{o} 6 \& \mathrm{pa}$ ge $=1 \&$ doc $=1>$. Accessed: Jan. 05, 2011. doi: 10.1007/s10722007-9285-7.

ROSADO, T.B. et al. Avaliação da diversidade genética do banco de germoplasma de pinhão-manso por marcadores moleculares. Brasília: Embrapa Agroenergia, 2009. 16p. (Boletim de Pesquisa e Desenvolvimento, 1). Available from: $<$ http://www.infoteca.cnptia.embrapa.br/bitstream/doc/661513/1/ BPesq01.pdf $>$. Accessed: Jan. 10, 2010.

SILVA, A.V.C.; MARTINS, A.B.G. Identificação de marcas moleculares associadas à ausência de sementes em videira. Ciência Rural, v.36, n.3, p.801-806, 2006. Available from:
$<$ http://www.scielo.br/scielo.php?script=sci_arttext\&pid=S010384782006000300012\&lng=en\&nrm=iso $>$. Accessed: Jun. 28, 2010. doi: $10.1590 / \mathrm{S} 0103-84782006000300012$.

SILVA, A.V.C. et al. Moringa genetic diversity from germplasm bank using RAPD markers. Tropical and Subtropical Agroecosystems, v.15, n.1, p.31-39, 2012. Available from: $<$ http://www.veterinaria.uady.mx/ojs/index.php/TSA/article/ view/1266/632>. Accessed: Mar. 05, 2012.

SUN, Q.B. et al. SSR and AFLP markers reveal low genetic diversity in the biofuel plant: Jatropha curcas in China. Crop Science, v.48, p.1865-1871, 2008. Available from: <https:// www.crops.org/publications/cs/articles/48/5/1865?highlight $=>$. Accessed: Jan. 12, 2010. doi: 10.2135/cropsci2008.02.0074.

WIESENHÜTTER, J. Use of the physic nut (Jatropha curcas L.) to combat desertification and reduce poverty. Bonn: GTZ, 2003. 18p. (CCD Project Document). Available from: $<$ http:// www.underutilized-species.org/documents/Publications/use_of jatropha_curcas_en.pdf $>$. Accessed: Feb. 20, 2010.

ZHAO, K. et al. Genetic diversity and discrimination of Chimonanthus praecox (L.) link germplasm using ISSR and RAPD Markers. Hortscience, v.42, p.1144-1148, 2007. Available from: $\quad<$ http://hortsci.ashspublications.org/content/42/5/1144. full?sid=d70049aa-a1 ee-4716-afcb-dea5030f27c4>. Accessed: Jan. 22, 2010. 